\title{
EFNB2 wt Allele
}

National Cancer Institute

\section{Source}

National Cancer Institute. EFNB2 wt Allele. NCI Thesaurus. Code C105842.

Human EFNB2 wild-type allele is located in the vicinity of $13 q 33$ and is approximately 45 $\mathrm{kb}$ in length. This allele, which encodes ephrin-B2 protein, plays a role in intercellular signal transduction. 